\title{
EFEKTIFITAS PENYELESAIAN PEMBATALAN PERATURAN DAERAH MELALUI METODE KEBERATAN DI MAHKAMAH AGUNG OLEH PEMERINTAH DAERAH KOTA/KABUPATEN
}

\author{
Fatkhurohman \\ Miftachus Sjuhad \\ Universitas Widyagama Malang \\ Email: Kusumo uwg@yahoo.co.id
}

\begin{abstract}
The objective of this study is to observe the effectiveness of local regulations annulment/ cancellation of the resolution process through a method of objections in the Supreme Court of the Republic of Indonesia (MA RI) conducted by the Local Government Pasuruan and Lumajang, Ministry of Home Affairs, and Supreme Court of the Republic of Indonesia (MA RI). This study is an empirical law. Data includes primary and secondary data. Data collection was conducted by the research study documents, observation and depth interviews. Considering the objectives of data juridical technical data was analyzed by qualitative analysis that the results presented in the form of descriptive. The results indicated that most local governments are reluctant proceedings to the Supreme Court after a local regulation canceled by the central government, so that the resolution process through methods objection is not so effective. In addition, due to the ineffectiveness of these efforts rather than by factors of legislation, law enforcement and infrastructure proposition but rather was caused by low participation and awareness of local government law, consequently led to legal uncertainty.
\end{abstract}

Keyword: Keywords: Effectiveness, Cancellation, Local Government

\begin{abstract}
Abstrak
Penelitian ini bertujuan untuk melihat efektifitas proses penyelesaian pembatalan peraturan daerah melalui metode keberatan di Mahkamah Agung Republik Indonesia (MA RI) yang dilakukan oleh Pemerintah Daerah Kabupaten Pasuruan dan Kabupaten Lumajang, Departemen Dalam Negeri RI, dan MA RI. Penelitian ini merupakan penelitian hukum empiris. Data meliputi data primer dan sekunder. Pengumpulan data penelitian dilakukan dengan studi dokumen, observasi, dan depth interview. Mengingat sasaran data bersifat yuridis maka teknis analisis data dilakukan dengan analisis kualitatif yang hasilnya dipaparkan dalam bentuk deskriptif. Hasil penelitian menunjukan bahwa sebagian besar pemerintah daerah enggan beracara ke Mahkamah Agung RI setelah peraturan daerahnya dibatalkan oleh pemerintah pusat, sehingga proses penyelesaian melalui metode keberatan ini tidak begitu efektif. Di samping itu ketidakefektifan upaya ini disebabkan bukan oleh faktor perundang-undangan, penegak hukum dan saranan prasarana tetapi lebih disebabkan oleh rendahnya partisipasi dan kesadaran hukum pemerintah daerah, akibatnya menyebabkan terjadinya ketidakpastian hukum.
\end{abstract}

Kata kunci: Efektivitas, Pembatalan, Pemerintah Daerah

\section{A. Pendahuluan}

Pada penelitian tahun pertama diketemukan telah terjadi ketidaktepatan proporsi teori penegakan hukum dalam sistem peradilan di Indonesia pada masalah pembatalan perda oleh pemerintah pusat (Fatkhurrohman, 2009). Hal ini disebabkan oleh sistem peradilan Indonesia belum mengatur penyelesaian sengketa perda khususnya dalam lingkup kewenangannya (Sukowiyono, 2004: 34). Hal ini terbukti pada ketentuan Pasal 10 UU No.4 Tahun 2004 tentang Pembentukan Peraturan perundang-undangan ternyata hanya mengatur empat hal yakni; Peradilan Umum, Peradilan
Agama, Peradilan Militer dan Peradilan Tata Usaha Negara. Dengan demikian sangat jelas bahwa sengketa atas keputusan pembatalan perda sebenarnya tidak termasuk dalam kompetensi keempat lingkungan peradilan dimaksud.

Tawaran teori untuk mengisi dan menyelesaikan problema regulasi ini adalah dengan menambahkan kewenangan Mahkamah Agung melalui pendirian peradilan konstitusi, sedangkan pada tataran tehnis diperlukan optimalisasi eksekutif review dan perlunya mencoba instrument judicial preview. Dalam jangka pendek prioritas utamanya adalah tertumpu kepada optimalisasi eksekutif review. 
Di sisi lain, tawaran pemikiran ini ternyata juga masih menyisakan masalah yang perlu dikaji secara mendalam yakni pemerintah daerah enggan berurusan dengan pemerintah pusat di Mahkamah Agung Republik Indonesia. Berdasarkan pemantauan awal ternyata tidak semua daerah senang menempuh cara ini. Bagi pemerintah daerah ketika perda dibatalkan pemerintah pusat maka langkah pencabutan perda adalah jalan yang paling baik.

Atas dasar kenyataan ini maka akan dikaji secara mendalam tentang efektifitas hukum atas sengketa pemerintah pusat dengan daerah. Dengan upaya ini nantinya akan terlihat unsur-unsur penegakan hukum mana yang tidak efektif. Karena itu hal ini penting untuk terus ditangani secara benar dan terukur mengingat keberadaan perda sangat dekat dengan kehidupan masyarakat daerah. Sistem regulasi daerah yang kuat jelas akan berimplikasi kepada sistem regulasi nasional. Dari kenyataan ini maka peneliti akan mengkajinya melalui dua sistem pendekatan, yakni dengan melihat kemauan daerah beracara di Mahkamah
Agung Republik Indonesia. Kalau secara empiris daerah banyak menggunakan hak beracaranya di Mahkamah Agung Republik Indonesia berarti pola penyelesaian sengketa antara pemerintah pusat dan daerah dianggap efektif. Tetapi, kalau sebaliknya ketika pemerintah daerah tidak banyak menggunakan hak beracaranya berarti sengketa tidak dikatakan tidak efektif.

Dari dua asumsi temuan ini peneliti membuktikan secara ilmiah melalui observasi langsung kepada daerah-daerah yang menjadi lokasi penelitian, yakni Kabupaten Pasuruan dan Kabupaten Lumajang.

Berdasarkan urian di atas permasalahan penelitian ini adalah, pertama, bagaimana efektifitas penegakan hukum setelah daerah menyatakan keberatan terhadap pembatalan perda oleh pemerintah pusat di Mahkamah Agung Republik Indonesia?, kedua, unsur-unsur apa yang mempengaruhi efektifitas penegakan hukum terhadap keberatan pembatalan perda oleh pemerintah pusat di Mahkamah Agung Republik Indonesia?

BAGAN ALIR MASALAH

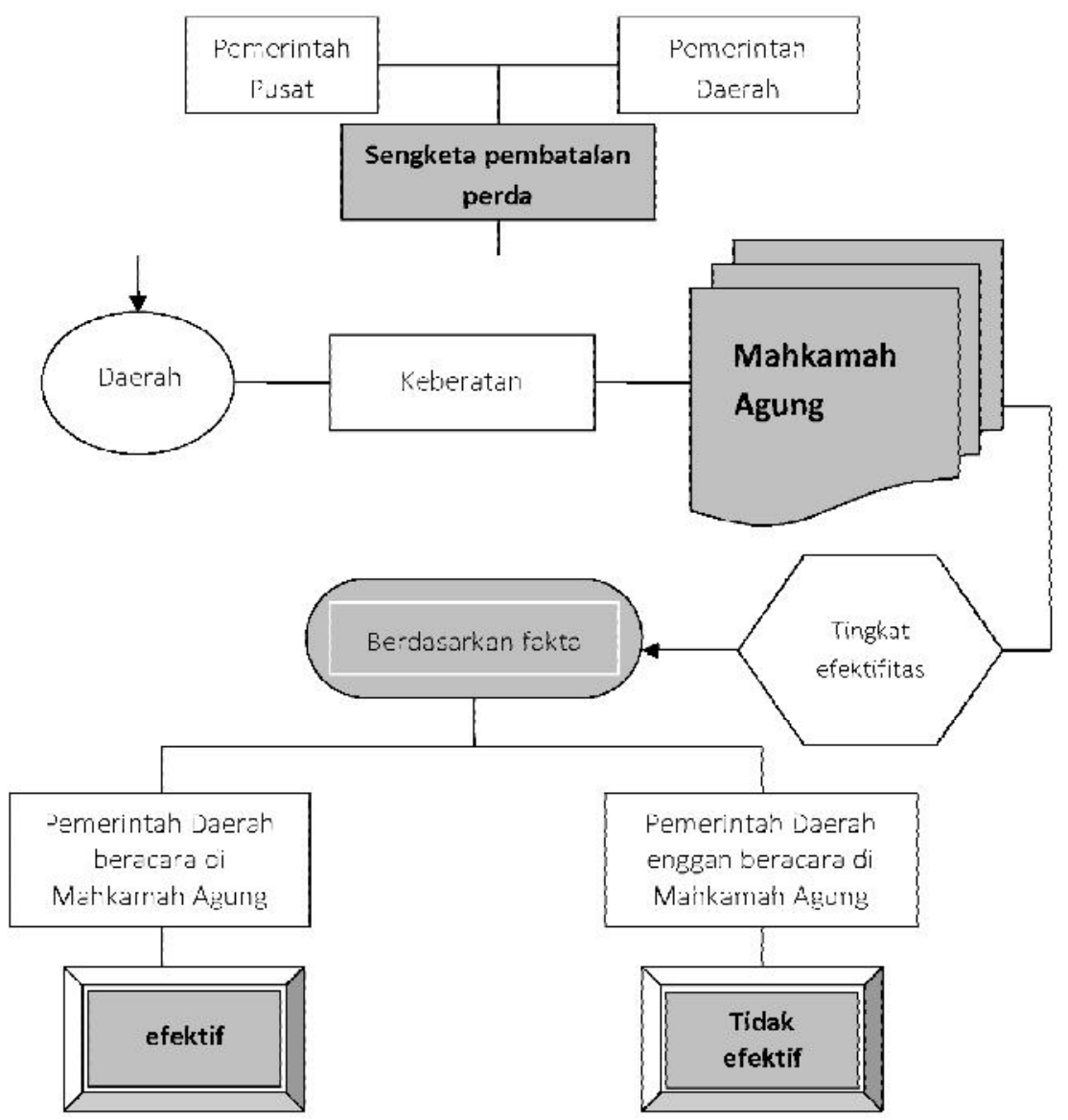

Yustisia Vol.1 No. 3 September - Desember 2012 


\section{B. Metode Penelitian}

Jenis penelitian ini adalah yuridis empiris / empiric legal research (Soetandyo Wignjosoebroto, 2002:15). Lokasi penelitian di Kabupaten Pasuruan dan Kabupaten Lumajang, Departemen Dalam Negeri, dan Mahkamah Agung Republik Indonesia. Data yang diperlukan dalam penelitian ini adalah data primer dan data sekunder. Pengumpulan data penelitian akan dilakukan dengan menggabungkan antara studi dokumen, observasi, dan depth interview. Dengan menggabung-kan tiga cara dalam pengumpulan data diperoleh keterangan-keterangan obyektif realistis dari sumber data yang dituju. Objektivitas dan kemurnian data akan sangat mempengaruhi validitas temuan dan pada akhirnya akan mempengaruhi kualitas hasil penelitian. Mengingat sasaran data bersifat yuridis, maka teknis analisis data dilakukan dengan analisis kualitatif dan hasilnya dipaparkan dalam bentuk deskriptif.

\section{Hasil Penelitian dan Pembahasan}

1. Efektifitas Penegakan Hukum Setelah Daerah Menyatakan Keberatan Pembatalan Peraturan Daerah oleh Pemerintah Pusat di MARI

Di tengah perkembangan era otonomi daerah, isu hukum muncul ketika pasca pembatalan peraturan daerah yang dilakukan oleh pemerintah pusat, yaitu tentang efektifitas penegakan hukum ketika didapatkan banyaknya jumlah daerah yang enggan mengajukan keberatan terhadap pembatalan peraturan daerah oleh pemerintah pusat di Mahkamah Agung Republik Indonesia(Wawan Kurnia dan Wastu, Wawancara, 2012). Dari sumber yang diperoleh dari jumlah upaya keberatan yang dilakukan oleh pemerintah daerah yang mengajukan keberatan ke Mahkamah Agung Republik Indonesia tidak sebanding dengan peraturan daerah yang dibatalkan pemerintah pusat melalui Keputusan Menteri Dalam Negeri.

Tabel 1

Produk Peraturan Daerah yang dibatalkan pemerintah melalui Keputusan Menteri Dalam Negeri

\begin{tabular}{|c|c|c|c|c|c|c|}
\hline \multirow{2}{*}{ No. } & \multirow{2}{*}{ Tahun } & \multicolumn{5}{|c|}{ Produk Hukum Daerah } \\
\cline { 3 - 7 } & $\begin{array}{c}\text { Perda } \\
\text { Retribusi }\end{array}$ & $\begin{array}{c}\text { Perda } \\
\text { Pajak }\end{array}$ & $\begin{array}{c}\text { Keputusan } \\
\text { Gubernurl } \\
\text { Bupati/Walikota }\end{array}$ & Lain-lain & Jumlah \\
\hline 1 & 2002 & 13 & 1 & - & 5 & 19 \\
\hline 2 & 2003 & 55 & 7 & 2 & 41 & 105 \\
\hline 3 & 2004 & 162 & 19 & 2 & 82 & 265 \\
\hline 4 & 2005 & 73 & 17 & 6 & 30 & 126 \\
\hline 5 & 2006 & 70 & 9 & 5 & 30 & 114 \\
\hline 6 & 2007 & 124 & 9 & 3 & 37 & 173 \\
\hline 7 & 2008 & 142 & 40 & 1 & 46 & 229 \\
\hline 8 & 2009 & 496 & 133 & 16 & 70 & 715 \\
\hline \multicolumn{2}{|c|}{ Total } & 1135 & 235 & 35 & 341 & 1746 \\
\hline
\end{tabular}

Sumber: Keputusan Kementrian Dalam Negeri tentang Pembatalan Peraturan Daearah dan Keputusan KDH Tahun 2002-2009

Dari total produk hukum daerah yang dibatalkan oleh Pemerintah selama 2002-2009, ternyata tidak banyak upaya keberatan yang dilakukan kepala daerah untuk mengajukan permohonan keberatan atas pembatalan peraturan daerah melalui Keputusan Menteri Dalam Negeri yang membatalkan peraturan daerah ke Mahkamah Agung Republik Indonesia (Siwi Tri Puji, 2011).

28 Yustisia Vol.1 No. 3 September-Desember 2012
Berdasarkan keterangan Kepmendagri terbaru, bahwa sepanjang Tahun 2009-2012 Kemendagri telah mengevaluasi sekitar 13.000 perda yang sebanyak 824 perda telah diklasifikasi dan dinyatakan salah karena tidak sesuai dengan aturan di atasnya,(Safri Nugraha ,2004:29) bertentangan dengan kepentingan umum, atau mengganggu ketentraman dan ketertiban (Harian Kompas, 2012). Selain itu, 
juga menghambat upaya memperbaiki perekonomian daerah (Umbu Lily Pekuwali, 2010: 105-106).

Realita ini menunjukan bahwa terjadi ketidak sebandingan fakta antara jumlah perda yang dibatalkan dan keberatan daerah yang berakhir di Mahkamah Agung Republik Indonesia. Proses penyelesaian ini menjadi tidak seimbang disebabkan daerah tidak banyak mempergunakan hak menuntut pemerintah pusat melalui upaya keberatan setelah perda dibatalkan oleh pemerintah pusat. Padahal Undang Undang menjamin bahwa upaya keberatan tersebut diberikan kepada kepala daerah. Ini yang menurut Esmi Warasih telah hilang sebuah cita hukum ketika tanpa cita hukum hukum akan kehilangan maknanya (Esmi Warasih, 2001: 354-361). Mengenai hal ini selanjutnya lihat dalam bagan berikut seperti digambarkan dalam penelitian sebelumnya, yaitu (Fatkhurohman, 2010: 54):

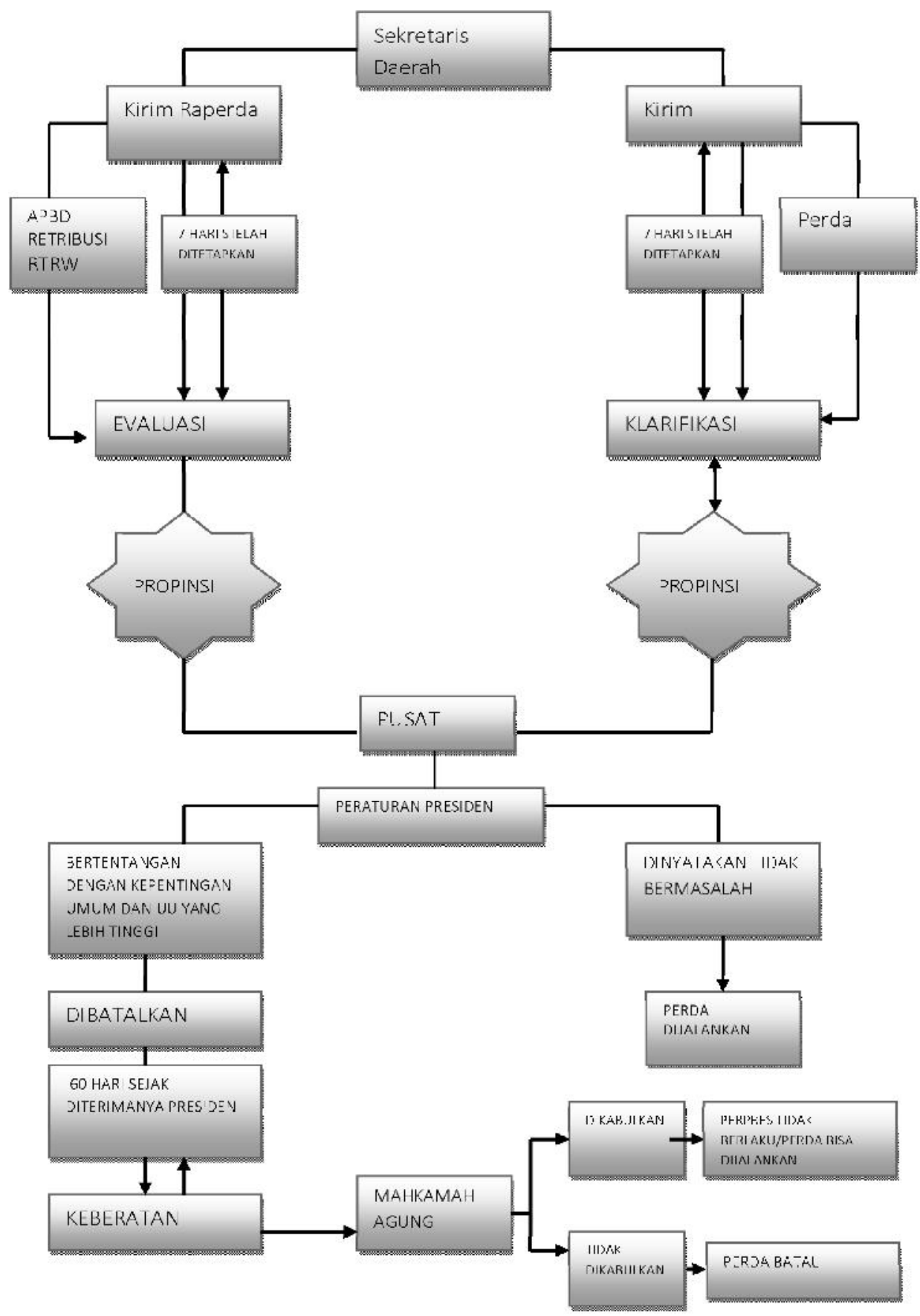


Menurut hasil penelitian yang dilakukan peneliti baik di Pemerintah Kabupaten Malang, Kabupaten Pasuruan dan Lumajang terjadinya keengganan daerah untuk beracara di Mahkamah Agung ketika perdanya dibatalkan oleh pemerintah pusat disebabkan oleh beberapa hal, yakni (Saiful, Wawancara, 2012):

a. pemerintah daerah menerima apa adanya keputusan pemerintah pusat dengan cara langsung menindak lanjuti hasil pembatalan pemerintah pusat dengan tidak memberlakukan perda yang ada;

b. pemerintah daerah beranggapan beracara di Mahkamah Agung (MA) banyak membuang waktu dan energi, mengingat banyak pekerjaan lain yang harus dikerjakan;

c. pemerintah daerah takut akan bayangan sanksi tersembunyi yang akan diberikan ketika berhadap-hadapan dengan pemerintah pusat.

Dengan melihat hasil ini maka dapat dikatakan bahwa efektifitas penegakan hukum setelah daerah menyatakan keberatan terhadap pembatalan perda oleh pemerintah pusat di Mahkamah Agung Republik Indonesia menjadi tidak efektif. Ada tiga faktor yang mempengaruhi efektifitas penegakan hukum, yakni: pertama, faktor substansi hukum, adalah aturan, norma, dan pola perilaku nyata manusia yang berada dalam sistem itu. Substansi juga berarti produk yang dihasilkan oleh orang yang berada dalam sistem hukum itu, mencakup keputusan yang mereka keluarkan, aturan baru yang mereka susun. Substansi juga mencakup Living Law (hukum yang hidup), dan bukan hanya aturan yang ada dalam kitab UndangUndang. Kedua, faktor struktural dalam hal ini adalah bagian yang tetap bertahan, bagian yang memberi semacam bentuk dan batasan terhadap keseluruhan. Di Indonesia misalnya, jika membahas tentang struktur sistem hukum Indonesia maka termasuk di dalamnya struktur institusi penegak hukum seperti kepolisian, kejaksaan, dan pengadilan. Juga termasuk unsur struktur jumlah dan jenis pengadilan, yurisdiksinya (jenis kasus yang berwenang untuk diperiksa, serta bagaimana dan mengapa). Jelasnya struktur bagaikan foto diam yang menghentikan gerak. Ketiga, faktor kultural dalam hal ini sikap manusia dan sistem hukum-kepercayaan, nilai pemikiran serta harapannya. Dengan kata lain kultur hukum adalah suasana pikiran sosial yang menentukan bagaimana hukum digunakan, dihindari atau disalahgunakan. Tanpa kultur hukum maka hukum tak berdaya, seperti ikan mati yang terkapar dikeranjang dan bukan seperti ikan hidup yang berenang di laut (Lawrance M. Friedman, 1975: 87).

Ketidakefektifan ini semakin menjadi ketika pemerintah daerah masih saja memberlakukan peraturan daerah meski dinyatakan bermasalah. Menurut Endi Jaweng manajer Hubungan Eksternal Komite Pemantauan Pelaksanaan Otonomi daerah (KPPOD), pemerintah daerah tetap memberlakukan perda bermasalah karena paham betul bahwa pembatalan perda, sesuai dengan UU 28 Tahun 2009 tentang Pajak daerah dan Retribusi Daerah hanya dapat dilakukan Presiden. Klarifikasi tidak bisa membatalkan perda. Klarifikasi malah diartikan sebagai permintaan untuk revisi yang boleh dikerjakan (Kompas, 2012).

Masalah ini juga disebabkan oleh problem kewenangan pembatalan perda yang seharusnya menjadi kewenangan presiden ternyata kewenangan itu banyak digunakan oleh Menteri Dalam Negeri. Hal ini seperti dikatakan oleh Mendagri Gamawan Fauzi meski kewenangan pembatalan di tangan presiden, dirinya tetap bisa mengevaluasi dan mengklarifikasi atas nama presiden. Untuk pengawasannya, Kemendagri berkoordinasi dengan instansi lain seperti Badan Pemeriksa Keuangan dan Komisi Pemberantasan Korupsi. Philipus M. Hadjon menjelaskan beberapa bentuk pengawasan dan kotrol, antara lain: pengawasan represif, yaitu pengawasan yang dilakukan kemudian. keputusan-keputusan badan-badan yang bertingkat lebih rendah akan dicabut kemudian apabila bertentangan dengan undang-undang atau kepentingan umum. Dalam situasi yang menuntut tindakan cepat dapat juga diambil tindakan penangguhan keputusan, sebelum dilakukan pencabutan. Pengawasan preventif yaitu pengawasan yang dilakukan sebelumnya. Pengawasan preventif adalah pengawasan terhadap keputusan-keputusan dari aparat pemerintah yang lebih rendah yang dilakukan sebelumnya (Philipus Hadjon, 1995: 74-75). Perlu diketahui selama sembilan tahun sampai hari ini presiden belum pernah membatalkan satu pun perda bermasalah. Dalam teori pendelegasian wewenang hal ini lazim terjadi dan dapat dibenarkan. Menurut Jimly Ashiddiqie proses pemberian kewenangan tingkat kedua ini dapat disebut (nantinya) juga dengan sub delegasi atau sub delegation of rule making power (Jimly Ashiddiqie, 2008:341). 
Berdasarkan kenyataan ini dapatlah digaris bawahi bahwa ketika pemerintah daerah enggan beracara di Mahkamah Agung Republik Indonesia atas pembatalan perdanya maka mekanisme penegakan hukum menjadi tidak efektif. Hal ini menimbulkan ketidakpastian hukum. Padahal kepastian hukum hanyalah suatu jalan menuju terciptanya keadilan. Kepastian hukum bertumpu pada dua komponen utama, pertama, kepastian dalam orientasi bagi masyarakat (berlakuknya asas kepastian orientasi), kedua, kepastian dalam penerapan hukum oleh penegak hukum (Abdul Latif, 2010: 54-55). Efektivitas hukum akan terlihat seberapa jauh hukum itu dipatuhi atau ditaati oleh masyarakat (Arfan Fais.M, 2009:155-156). Makna berlakunya hukum menjadi rusak. Padahal hukum merupakan sarana yang di dalamnya terkandung nilai-nilai atau konsep-konsep tentang keadilan, kebenaran, kemanfaatan sosial dan sebagainya (HR Ridwan, 2007: 306). Muara hukum yang begitu mendalam ini tergantung kepada penegakan hukum. Menurut Satjipto Rahardjo penegakan hukum pada hakekatnya merupakan penegakan ide-ide atau konsep konsep yang abstrak (Satjipto Rahardjo, 2009: 15).

Soerjono Soekanto juga menegaskan, penegakan hukum adalah kegiatan menyerasikan hubungan nilai-nilai yang terjabarkan di dalam kaedah-kaedah/pandangan-pandangan nilai yang mantap dan mengejawantah dan sikap tindak sebagai rangkaian nilai tahap akhir untuk menciptakan (sebagai "social control) kedamaian pergaulan hidup (Soerjono Soekanto, 1983: 13). Pada tingkatan konkrit maka penegakan hukum adalah berlakunya hukum positif dalam praktik sebagaimana seharusnya patut ditaati. Oleh karena itu, memberikan keadilan dalam suatu perkara berarti memutuskan perkara dengan menerapkan hukum dan menemukan hukum in concreto dalam mempertahankan dan menjamin ditaatinya hukum materiil dengan menggunakan cara prosedural yang ditetapkan oleh hukum formal (Sjachran Basah, 1985: 14).

Fakta penegakan hukum pada persoalan ini ketika dihubungkan dengan pengertian di atas maka sepertinya menimbulkan kontradiksi tujuan yang cukup tajam. Hal ini disebabkan pemerintah daerah yang seharusnya mendapatkan keadilan, kebenaran dan kemanfaatan sosial dalam perkara pembatalan perda malah tidak menginginkan hal tersebut. Sebuah fenomena yang sangat tidak lazim pada proses penegakan hukum (law enforcement). Disini telah terjadi kelumpuhan hukum bukan karena hukum tidak bisa bekerja, tetapi lebih disebabkan oleh pemerintah daerah mau menggunakan sarana untuk beracara karena alasan-alasan yang sangat pragmatis. Dengan demikian, tujuan berlaku dan berfungsinya hukum dalam masalah ini tidak tercapai. Demikian juga efektifitas berlakunya peraturan perundang-undangan yang terkait ini menjadi mandul secara tersetruktur.

Kenyataan ini sangat kontrakditif dengan pendapatnya Jimly Ashiddiqie yang menyatakan bahwa gagasan negara hukum dibangun dengan mengembangkan perangkat hukum itu sendiri sebagai suatu sistem yang fungsional dan berkeadilan, dikembangkan dengan supra stuktur dan infra stuktur kelembagaan politik, ekonomi dan sosial yang tertib dan teratur, serta dibina dengan membangun budaya dan kesadaran hukum yang rasional dan impersonal dalam kehidupan bermasyarakat, berbangsa dan bernegara. Untuk itu sistem hukum harus dibangun (law making process) dan ditegakkan (law enforcement) sebagai mestinya, dimulai sebagai konstitusi sebagai hukum yang tertinggi kedudukanya (Jimly Ashiddiqie, 2010:27).

2. Unsur-unsur yang Mempengaruhi Efektifitas Penegakan Hukum terhadap Keberatan Pembatalan Perda oleh Pemerintah Pusat di MA RI

Dalam peraturan perundang-undangan baik saat berlakunya UU No.10/2004 maupun UU No.11/2012 tentang Pembentukan Peraturan Perundang-undangan, perda memiliki posisi yang unik karena meski kedudukan Perda berada di bawah UndangUndang tetapi tidak terdapat kesatuan pendapat antara para pakar mengenai siapa sebenarnya yang berwenang mengujinya antara Pemerintah Pusat melalui mekanisme executive review atau diberikan kepada lembaga yudikatif (MA/MK) dengan mekanisme judicial review.

Perdebatan mengenai berlakunya executive review dan judicial review terhadap perda menjadi pertanyaan tersendiri di era otoda ini mengingat perda adalah produk kepala daerah dan DPRD di suatu daerah yang bersifat otonom. Dalam Undang-undang Nomor 12 Tahun 2011 tentang Pembentukan Peraturan Perundang-undangan disebutkan bahwa materi muatan Perda mencakup tiga hal, yaitu: 
(a) seluruh materi muatan dalam rangka penyelenggaraan otonomi daerah dan tugas pembantuan;

(b) menampung kondisi khusus daerah, dan

(c) penjabaran lebih lanjut peraturan perundang-undangan yang lebih tinggi.

Oleh karena itu, dalam Undang-Undang Nomor 32 Tahun 2004 tentang Pemerintahan Daerah ditegaskan bahwa sebuah perda tidak boleh atau dilarang bertentangan dengan kepentingan umum dan/atau peraturan perundang-undangan yang lebih tinggi.

Apabila sebuah perda bertentangan dengan kepentingan umum dan/atau peraturan perundang-undangan yang lebih tinggi, maka perda tersebut dapat dibatalkan oleh pemerintah. Akibat hukum perda yang dibatalkan adalah paling lama tujuh hari setelah keputusan pembatalan, perda tersebut dihentikan pelaksanaannya oleh kepala daerah, selanjutnya DPRD bersama kepala daerah mencabut perda tersebut. Akan tetapi, pembatalan perda oleh pemerintah pusat tidak dapat dilakukan secara sewenang-wenang. Ada syarat dan mekanisme sebuah perda dapat dibatalkan oleh pemerintah. Syarat utama pembatalan perda adalah bahwa keputusan pembatalan perda harus ditetapkan dengan Peraturan Presiden (Pasal 145 Ayat 3 UU 32/2004).

Peraturan Presiden (Perpres) adalah salah satu jenis peraturan perundang-undangan yang dibuat oleh presiden yang materinya berupa materi yang diperintahkan oleh Undang-Undang atau materi untuk melaksanakan Peraturan
Pemerintah (PP). Dengan demikian, pembatalan Perda melalui Keputusan Menteri Dalam Negeri (Kepmendagri) merupakan sebuah kekeliruan hukum. Kekeliruan itu terjadi karena instrumen hukum untuk membatalkan Perda harus dalam bentuk perpres bukan kepmendagri. Mengingat Perda masuk dalam rumpun regeling dibatalkan oleh keputusan yang masuk dalam rumpun beschikking. Keberadaan Kepmen-dagri yang membatalkan Perda merupakan penggunaan kewenangan yang tidak pada tempatnya (ultra vires).

Meskipun demikian, dalam prakteknya sampai bulan Juli 2012 hasil penelitian penulis, pembatalan perda masih menggunakan kepmendagri yang sejatinya merupakan sebuah kekeliruan hukum dan anehnya pemerintah daerah yang perdanya dibatalkan dengan instrumen hukum kepmendagri tidak mempermasalahkan bahkan berjalan dengan normal saja. Yang seharusnya dilakukan Pemda jika Perda-nya dibatalkan dengan kepmendagri mereka bisa saja tidak mentaatinya karena jelas itu bertentangan dengan Pasal 145 ayat (3) UU 32/2004.

Hal itu bisa terlihat dari adanya upaya hukum yang dilakukan oleh pemda untuk mengajukan gugatan pembatalan perda di Mahkamah Agung Republik Indonesia yang dibatalkan oleh Pemerintah Pusat c.q. Menteri Dalam Negeri melalui kepmendagri. Berikut hasil pengidentifikasian PUTUSAN sengketa Perda yang dilakukan gugatan Uji Materiil di Mahkamah Agung dalam kurun waktu sampai bulan Juli tahun 2012:

Tabel 2

Keputusan atas Gugatan Keberatan Pemerintah Daerah di Mahkamah Agung Republik Indonesia

\begin{tabular}{|c|l|l|c|}
\hline No & \multicolumn{1}{|c|}{ Putusan } & \multicolumn{1}{c|}{ Hak Uji Terhadap } \\
\hline 1. & $\begin{array}{l}\text { Nomor. 14 } \\
\text { P/HUM/2004 }\end{array}$ & $\begin{array}{l}\text { Hak Uji Material Keputusan Menteri Dalam Negeri Republik Indonesia Nomor 142 } \\
\text { Tahun 2003 tentang Pembatalan Peraturan Daerah Kabupaten Kotawaringin } \\
\text { Timur Nomor 16 Tahun 2001 Tentang Usaha Pemanfaatan Kawasan Hutan dan } \\
\text { Hasil Hutan Kabupaten Kotawaringin Timur }\end{array}$ \\
\hline 2. & $\begin{array}{l}\text { Nomor. 09 } \\
\text { PlHUM/2004 }\end{array}$ & $\begin{array}{l}\text { Hak Uji Material Keputusan Menteri Dalam Negeri Republik Indonesia No.141 } \\
\text { Tahun 2003 tentang pembatalan Perda No.19 Tahun } \\
\text { Kepelabuhanan Kabupaten Gresik }\end{array}$ \\
\hline 3. & $\begin{array}{l}\text { Nomor. 14 } \\
\text { PlHUM/2004 }\end{array}$ & $\begin{array}{l}\text { Hak Uji Material terhadap Keputusan Menteri dalam Negeri No.142 Tahun 2003 } \\
\text { tentang Perda No.16 Tahun 2001 Tentang Usaha Pemanfaatan Kawasan Hutan } \\
\text { Dan Hasil Hutan Kabupaten Kotawaringin Timur }\end{array}$ \\
\hline 4. & $\begin{array}{l}\text { Nomor. 08 } \\
\text { PlHUM/2004 }\end{array}$ & $\begin{array}{l}\text { Hak Uji Material terhadap Keputusan Menteri Dalam Negeri Nomor 110 Tahun } \\
\text { 2003 tentang Pembatalan Pasal 3, 6, 13, 14, 15, 16, 17, 18, dan 19 Peraturan } \\
\text { Daerah Kabupaten Gresik Nomor 3 Tahun 2001 tentang Penataan Ruang Pantai } \\
\text { Pesisir dan Pelabuhan Tahun 2000 Samapai dengan 2010 }\end{array}$ \\
\hline 5. & $\begin{array}{l}\text { Nomor 09 } \\
\text { PlHUM/2004 }\end{array}$ & $\begin{array}{l}\text { Hak Uji Material terhadap Keputusan Menteri Dalam Negeri No. 141 Tahun 2003 } \\
\text { tentang Pembatalan Peraturan Daerah Kabupaten Gresik No. 19 Tahun 2001 } \\
\text { tentang Kepelabuhan di Kabupaten Gresik }\end{array}$ \\
\hline
\end{tabular}




\begin{tabular}{|c|l|l|}
\hline 6. & $\begin{array}{l}\text { Nomor. 17 } \\
\text { P/HUM/2005 }\end{array}$ & $\begin{array}{l}\text { Hak Uji Material Keputusan Menteri Dalam Negeri Republik Indonesia No. 20 } \\
\text { Tahun 2005 tentang pembatalan Perda Kota Bandung Nomor. 26 Tahun 2001 } \\
\text { tentang Pelayanan di Bidang Pertanian }\end{array}$ \\
\hline 7. & $\begin{array}{l}\text { Nomor20 } \\
\text { P/HUM/2007 }\end{array}$ & $\begin{array}{l}\text { Hak Uji Material terhadap Keputusan Menteri Dalam Negeri No. 73 Tahun 2007 } \\
\text { tentang Pembatalan Peraturan Daerah Kabupaten Nias No. 9 Tahun 2002 } \\
\text { tentang Retribusi Hasil Bumi }\end{array}$ \\
\hline 8. & $\begin{array}{l}\text { Nomor. 02 } \\
\text { P/HUM/2008 }\end{array}$ & $\begin{array}{l}\text { Hak Uji Material terhadap Keputusan Menteri Dalam Negeri Nomor 129 Tahun } \\
2007 \text { tentang Pembatalan Peraturan Daerah Kota Surabaya Nomor 7 Tahun } \\
\text { 2000 tentang Penyelenggaraan Parkiran }\end{array}$ \\
\hline 9. & $\begin{array}{l}\text { Nomor. 03 } \\
\text { P/HUM/2009 }\end{array}$ & $\begin{array}{l}\text { Hak Uji Material terhadap Keputusan Menteri Dalam Negeri Nomor 224 Tahun } \\
\text { 2008, tanggal 6 Agustus 2008, Tentang Pembatalan Peraturan Daerah } \\
\text { Kabupaten Tingkat II Magelang Nomor 1 Tahun 1999 tentang Pajak Hiburan } \\
\text { sebagaimana telah diubah beberapa kali terakhir dengan Peraturan Daerah Ka- } \\
\text { bupaten Magelang Nomor 3 Tahun 2003. }\end{array}$ \\
\hline
\end{tabular}

Sumber: Mahkamah Agung Republik Indonesia. (diolah)

Tabel 3

Pecabutan Proses Keberatan oleh Pemerintah Daerah di Mahkamah Agung Republik Indonesia

\begin{tabular}{|c|l|l|}
\hline No & \multicolumn{1}{|c|}{ Putusan } & \multicolumn{1}{c|}{ Hak Uji Terhadap } \\
\hline 1. & $\begin{array}{l}\text { No. 48 P/HUM/2006 } \\
\text { dicabut kembali dengan } \\
\text { Surat Pencabutan } \\
\begin{array}{c}\text { Permohonan keberatan Hak } \\
\text { Uji Materiil No.180/0671 }\end{array}\end{array}$ & $\begin{array}{l}\text { Hak Uji Material Keputusan Menteri Dalam Negeri Republik } \\
\text { Indonesia No.110 Tahun 2006 tentang pembatalan Perda } \\
\text { Kabupaten Asahan No.11 Tahun 2001 tentang Izin dan } \\
\text { Retribusi Izin Pergudangan di Kabupaten Asahan }\end{array}$ \\
\hline 2. & $\begin{array}{l}\text { No. 51 P/HUM/2006 } \\
\text { dicabut kembali dengan } \\
\text { Surat Pencabutan } \\
\begin{array}{l}\text { Permohonan keberatan Hak } \\
\text { Uji Materiil No.180/0671 }\end{array}\end{array}$ & $\begin{array}{l}\text { Hak Uji Material Keputusan Menteri Dalam Negeri Republik } \\
\text { Indonesia No.115 Tahun 2006 tentang pembatalan Perda } \\
\text { Kabupaten Asahan No. 5 Tahun 2004 Tentang Perizinan } \\
\text { di bidang Kesehatan }\end{array}$ \\
\hline 3. & $\begin{array}{l}\text { No. 55 P/HUM/2006 } \\
\text { dicabut kembali dengan } \\
\text { Surat Pencabutan } \\
\begin{array}{l}\text { Permohonan keberatan Hak } \\
\text { Uji Materiil No.180/0671 }\end{array}\end{array}$ & $\begin{array}{l}\text { Hak Uji Material terhadap Keputusan Menteri Dalam Negeri } \\
\text { No.117 Tahun 2006 tentang pembatalan Perda Kabupaten } \\
\text { Asahan No. 10 Tahun 2004 tentang Retribusi Pelayanan } \\
\text { Kesehatan Pada Pemerintah Kabupaten Asahan }\end{array}$ \\
\hline
\end{tabular}

Sumber Mahkamah Agung Republik Indonesia. (diolah)

Selama kurun waktu sampai bulan Juli 2012 ada gugatan hak uji materiil 168 kasus yg sudah di putus dan hanya 10 kasus sengketa perda yang ditangani dan diputus oleh Mahkamah Agung, dan ada 3 kasus yang kemudian keberatan ditarik kembali oleh pemerintah daerah.

Dengan demikian, dapat disimpulkan bahwa tidak banyak daerah yang menggunakan mekanisme hukum untuk melawan perda yang dibatalkan oleh pemerintah pusat meskipun secara hukum sudah diberikan kewenangannya untuk melakukan upaya hukum sengketa perda ke Mahkamah Agung Republik Indonesia. Hal inilah yang menurut Soerjono Soekanto telah terjadi kerusakan kesadaran hukum dan lemahnya partitisipasi (Soerjono Soekanto, 1983:340). Selain itu ternyata peristiwa ini, memberikan fakta bahwa peradilan ternyata tidak saja hanya ada sekedar ada, memiliki fasilitas yang diperlukan, ataupun mampu menyelesaikan perkara yang masuk, tetapi lebih dari itu harus menjadi lembaga yang bersih dan berwibawa dalam menegakan hukum dan keadilan (A. Latief Farikun, 2008:29-30). Peristiwa keengganan pemda untuk beracara secara langsung akhirnya telah mengurangi kewibawaan Mahkamah Agung Republik Indonesia.

Hasil penelitian yang penulis temukan terdapat beberapa unsur yang menyebabkan pemerintah daerah tidak memaksimalkan upaya hukum yang diberikan oleh UndangUndang, yaitu sebagai berikut. 
a. Perbedaan Penafsiran Kepentingan Umum

Pengujian perda oleh pemerintah atau yang dalam kajian pengujian peraturan (toetzingrecht) dikenal dengan istilah executive review lahir dari kewenangan pengawasan pemerintah pusat terhadap penyelenggaraan (otonomi) pemerintahan daerah. Dalam rangka pengawasan terhadap daerah, UU No.32 Tahun 2004 memberi perintah bahwa perda yang dibuat oleh DPRD bersama kepala daerah agar disampaikan kepada pemerintah paling lama tujuh hari setelah ditetapkan. Terkait pembatalan perda, Pasal 136 ayat (4) UU No. 32 Tahun 2004 menyebutkan bahwa "Perda dilarang bertentangan dengan kepentingan umum dan/atau peraturan perundang-undangan yang lebih tinggi."

Kemudian Pasal 145 ayat (2) UU tersebut menyebutkan "Perda yang bertentangan dengan kepentingan umum dan/atau peraturan perundang-undangan yang lebih tinggi dapat dibatalkan oleh pemerintah." Ayat (3) menyebutkan "Keputusan pembatalan Perda ...... ditetapkan dengan Peraturan Presiden paling lama 60 (enam puluh) hari sejak diterimanya Perda...", selanjutnya ayat (5) menyebutkan "Apabila provinsi/ kabupaten/kota tidak dapat menerima keputusan pembatalan Perda ...... dengan alasan yang dapat dibenarkan oleh peraturan perundang-undangan, kepala daerah dapat mengajukan keberatan kepada Mahkamah Agung."

Standar pengujian perda oleh pemerintah berbeda dengan standar pengujian perda yang dilakukan oleh Mahakamah Agung Republik Indonesia. Apabila Mahkamah Agung Republik Indonesia menguji suatu perda atas dasar apakah satu perda bertentangan atau tidak dengan peraturan yang lebih tinggi dan apakah prosedur pembuatan perda bertentangan dengan peraturan perundang-undangan, pemerintah melakukan pengujian perda dengan standar yang lebih luas. Dikatakan lebih luas karena pemerintah menguji perda tidak hanya didasarkan pada aturan hukum yang lebih tinggi dari perda, tetapi juga didasarkan pada standar kepentingan umum berdasar kepada Pasal 145 ayat (2) UU No.32 Tahun 2004 tentang pemerintahan daerah.
Hal inilah yang menimbulkan perbedaan penafsiran antara pemerintah pusat dengan pemerintah daerah yang pada prinsipnya sama-sama mementingkan dan memikirkan kepen-tingan umum dalam hal ini masyarakat secara keseluruhan.

Kepentingan umum adalah aspek yang bersifat sosiologis daripada legalistis. sehingga pengujian terhadap kepentingan umum bergantung pada aspek keberlakuan berbagai macam jenis hukum dan norma sosial yang ada dalam masyarakat. Dalam penjelasan Pasal 136 ayat (4) UU No. 32 Tahun 2004 disebutkan bahwa "Yang dimaksud dengan 'bertentangan dengan kepentingan umum' dalam ketentuan ini adalah kebijakan yang berakibat terganggunya kerukunan antar warga masyarakat, terganggunya pelayanan umum dan terganggunya ketenteraman/ketertiban umum serta kebijakan yang bersifat diskriminatif." Dengan demikian, bertentangan dengan kepentingan umum menjadi standar yang longgar yang ditafsirkan berdasarkan kekuasaan penafsir. Maka tidak jarang tafsir kepentingan umum lebih mewakili tafsir penguasa. Orientasi kekuasaanlah terkadang yang mewakili kepentingan umum. Pada hal penafsiran harus berorientasi kepada keadilan subtantif dari pada keadilan prosedural (Mahrus Ali, 2010: 80).

Dengan demikian, dapat dipastikan bahwa yang ditafsirkan pemerintah pusat mengenai makna 'kepentingan umum' dapat berbeda dengan yang dimaknai oleh pemerintah daerah. Pemerintah daerah membuat produk hukum berupa perda sudah pasti memperhatikan baik dari aspek filosofis, yuridis dan sosiologis. Tentunya pemerintah daerah betul-betul mempertimbangkan kebutuhan masyarakat di wilayah kekuasaannya, apa yang dibutuhkan dan apa kebutuhan masyarakat ialah pemerintah daerah yang mengetahui. Sehingga semuanya harus didasarkan belaka pada kepentingan dan kemaslahatan rakyat banyak selaku pemegang kedaulatan di negeri ini (Laica Marzuki, 2010: 27).

Hal ini dapat dilihat ketika tidak terjadi gejolak atau penolakan berlakunya suatu perda di masyarakat juga dapat dibatalkan oleh pemerintah atas dasar bertentangan dengan kepentingan umum. Begitu pula 
sebaliknya, apabila suatu perda dianggap menimbulkan masalah oleh masyarakat dapat saja tidak dibatalkan oleh pemerintah jika perda tersebut sesuai tafsir kekuasaan pemerintah, sehingga tertib peraturan perundang-undangan yang diupayakan lewat pengujian perda belum tentu berkontribusi kepada tertib sosial.

b. Menimbulkan Ketidakpastian Hukum

Dalam Pasal 145 ayat (5) UU No. 32/ 2004 sudah jelas menyebutkan "Apabila provinsi/kabupaten/kota tidak dapat menerima keputusan pembatalan Perda ... dengan alasan yang dapat dibenarkan oleh peraturan perundang-undangan, kepala daerah dapat mengajukan keberatan kepada Mahkamah Agung".

Wewenang MA terkait pembatalan Perda berdasarkan Pasal 145 ayat (6) UU Nomor 32/2004 terbatas hanya menerima keberatan terhadap daerah yang tidak terima pembatalan perda oleh pemerintah, dan tidak berwenang menguji, apalagi membatalkannya. Akan tetapi bila perda bertentangan dengan perundang-undangan yang lebih tinggi, maka asasnya ia tidak bisa diberlakukan, karena tidak punya kekuatan hukum lagi (Maria Farida, 2006:2).

Dasar kewenangan Mahkamah Agung Republik Indonesia dapat melakukan pengujian terhadap Peraturan Pemerintah (PP), Peraturan Presiden (Perpres), dan Peraturan Daerah (Perda) dimuat dalam beberapa peraturan perundang-undangan. Mulai dari dasar konstitusional dalam Pasal 24A ayat (1) UUD 1945, kemudian Pasal 11 ayat (2) huruf b UU No. 4 Tahun 2004 tentang Kekuasaan Kehakiman, selanjutnya Pasal 31 ayat (2) UU No. 5 Tahun 2004 tentang Mahkamah Agung memberi ukuran atau alasan suatu peraturan di bawah Undang Undang dapat dibatalkan, yaitu: 1) karena bertentangan dengan peraturan perundang-undangan yang lebih tinggi (aspek material); atau 2) pembentukannya tidak memenuhi ketentuan yang berlaku (aspek formal).

Untuk melaksanakan kewenangan pengujian peraturan perundang-undangan, Mahkamah Agung Republik Indonesia telah mengeluarkan Peraturan Mahkamah Agung (Perma) No. 1 Tahun 1999 tentang Hak Uji Material yang sudah diganti dengan Perma No. 1 Tahun 2004. Salah satu kelemahan dari Perma No. 1 Tahun 2004 tentang Hak Uji Materiil oleh Mahkamah Agung Republik Indonesia adalah tidak diaturnya batas waktu proses pengujian peraturan perundang-undangan, termasuk perda, oleh Mahkamah Agung. Misalnya kapan dan berapa lama waktu penunjukan majelis hakim dilakukan dan berapa lama waktu maksimal yang dapat digunakan majelis hakim untuk memeriksa perkara pengujian peraturan. Ketiadaan pengaturan batas waktu proses itu sangat ironis mengingat dalam perma tersebut Mahkamah Agung Republik Indonesia malah membatasi waktu hak warga negara untuk menyampaikan permohonan keberatan.

Perma No 1 Tahun 2004 juga tidak merumuskan ruang bagi masyarakat untuk dapat mengawasi jalannya proses pengujian oleh Mahkamah Agung Republik Indonesia. Nampak sekali bahwa Mahkamah Agung Republik Indonesia masih bersifat tertutup, padahal objek yang sedang disengketakan adalah objek yang terkait dengan kepentingan publik, yaitu suatu peraturan (regeling) yang berlaku umum di masyarakat.

Ketidakjelasan waktu itulah yang membuat enggan pemerintah daerah untuk melakukan gugatan sengketa perda di Mahkamah Agung Republik Indonesia, karena tidak adanya pengaturan batas waktu proses pengujian yang dilakukan oleh MARI akan menimbulkan ketidakpastian hukum. Itu dapat terlihat pada sengketa yang dilakukan oleh Walikota Bandung dengan dibatalkannya perda Kota Bandung Nomor 26 Tahun 2001 tentang Pelayanan di Bidang Pertanian, yang instrumen hukum pembatalannya melalui Kepmendagri No. 20 Tahun 2005, sedangkan sengketa perda tersebut diputus oleh Mahkamah Agung pada tanggal 25 Juli 2008, padahal gugatan hak uji material yang diajukan oleh Walikota Bandung pada tahun 2005 berdasarkan register di kepaniteraan Mahkamah Agung Republik Indonesia Nomor. 17 P/HUM/ 2005. Jika demikian, Pemerintah Kota Bandung menunggu selama tiga tahun tanpa ada kepastian nasib Perdanya.

\section{c. Terpusatnya Pengujian di Yudisial}

Melihat ketidakefektifan kewenangan hak uji material yang dilakukan 
oleh pemerintah daerah dalam gugatan sengketa perda, peneliti perlu mengkaji kembali apakah memang masih diperlukan Executivef Review yang dilakukan pemerintah pusat terhadap perda. Pada hal piranti ini berguna untuk menguji suatu peraturan perundang-undangan dan dapat membatalkannya apabila dipandang bertentangan dengan peraturan perundang-undangan yang lebih tinggi (Imam Soebechi, 2012: 187).

Jimly Asshiddiqie dalam bukunya "Hukum Acara Pengujian UndangUndang" menyatakan bahwa perda sebagai hasil kerja Kepala Daerah dan Dewan Perwakilan Daerah (DPRD) tidak dapat dibatalkan oleh keputusan sepihak dari pemerintah pusat begitu saja (Jimly Asshidiqie, 2006:37-39). Pemerin-tah pusat sudah seharusnya tidak diberi kewenangan oleh Undang-Undang untuk mencabut perda sebagaimana diatur oleh UU tentang Pemerintahan Daerah (UU No 32 Tahun 2004), hal demikian merupakan bentuk ketidakkonsistenan peraturan perundang-undangan. Perlu dipikirkan kembali untuk mengembalikan kewenangan pengujian perda sepenuhnya berada di lembaga yudisial atau Mahkamah agung sebagaimana ketentuan Pasal 24A ayat (1) UUD 1945. Dengan catatan ada perombakan kewenangan yang jelas di tubuh Mahkamah Agung Republik Indonesia agar sesuai sistem peradilan yang ada. Mengingat penyelesaian perda tidak masuk dalam rezim sistem peradilan yang ada di Indonesia (Fatkhurohman, 2009:2).

\section{Simpulan}

Berdasarkan hasil penelitian dan pembahasan dapat disimpulkan sebagai berikut.

1. Sebagian besar Pemerintah daerah enggan beracara ke Mahkamah Agung Republik Indonesia setelah peraturan daerahnya dibatalkan oleh pemerintah pusat, sehingga proses penyelesaian melalui metode keberatan ini tidak begitu efektif.

2. Ketidakefektifan upaya ini disebabkan bukan oleh faktor perundang-undangan, penegak hukum dan saranan prasarana, tetapi lebih disebabkan oleh rendahnya partisipasi dan kesadaran hukum pemerintah daerah, sehingga menyebabkan terjadinya ketidakpastian hukum.

\section{Daftar Pustaka}

A.Latief Fariqun. 2008. "Peran Hakim Dalam Membangun Negara Hukum Indonesia". Jurnal Konstitusi Kerjasama MKRI dengan Puskasi Fak.Hukum Univ.Widyagama Malang, Vol.I No.1. Oktober 2008

Arfan Faiz.M. 2009. "Reposisi Lembaga Pendidikan Hukum dalam Proses Legislasi di Indonesia”. Jurnal Konstitusi, Vol 6 Nomor 2, Februari 2009

Abdul Latif. 2010. “Jaminan UUD 1945 dalam Proses Hukum Yang Adil”. Jurnal Konstitusi, Vol 7 Nomor 1 , Februari 2010

Esmi Warassih P. 2001. "Fungsi Cita Hukum dalam Penyusunan Peraturan Perundangan Yang Demokratis". Arena Hukum Majalah Hukum FH Unibraw No. 15 tahun 4, November 2001

Fatkhurohman. 2009. "Pengaruh Otonomi Daerah terhadap Hubungan Pemda di bidang Regulasi untuk Menangani Perda Bermasalah (Studi di Kabupaten Malang)". Laporan Penelitian Fundamental DIPA DP2M Direktorat Pendidikan Tinggi (Dikti) Jakarta.

2010. "Pengaruh Otonomi daerah Terhadap Hubungan Pemda di bidang Regulasi Untuk menangani Perda Bermasalah (Studi di Kabupaten Malang)”. Jurnal Hukum Yustisia, FH UNS Surakarta Terakreditasi Edisi Nomor 79 Januari-April 201

Imam Soebechi. 2012. Judicial Review Perda Pajak dan Retribusi Daerah. Jakarta: Sinar Grafika Jimly Asshiddiqie. 2006. Hukum Acara Pengujian Undang-Undang. Jakarta: Sekretariat Jenderal MKRI 2008. Pokok-Pokok Hukum Tata Negara Indonesia. Jakarta: Rajawali Press 2010. Perkembangan \& Konsolidasi Lembaga Negara Pasca Reformasi. Jakarta: Sinar

Grafika 
Kompas. 2012, 23 Agustus. Pajak Retribusi, Peraturan Daerah Bermasalah Tak Berlaku

Kompas. 2012, 24 Agustus. Peraturan Bermasalah, Daerah Masih Bandel Memberlakukan

Lawrance M. Friedman. 1975. The Legal System: Social Science Perspective. New York: Russel sage Foundation

M. Laica Marzuki. 2010. "Permakzulan Presiden/Wakil Presiden Menurut Undang Undang Dasar 1945". Jurnal Konstitusi, Vol 7 Nomor 1, Februari 2010

Mahrus Ali. 2010. "Mahkamah Konstitusi dan Penafsiran Hukum yang Progresif", Jurnal Konstitusi, Vol 7 Nomor 1, Februari 2010.

Maria Farida. 2006. "Problematika Hukum Hak Uji Materiil dan Formal Peraturan Daerah" . http:// anggara.wordpress.com

Philipus M. Hadjon, et. Al, 1995. Pengantar Hukum Administrasi. cetakan kesebelas. Yogyakarta: Gadjah Mada University Press

Ridwan HR. 2007. Hukum Administrasi Negara. Jakarta:Rajawali Press

Safri Nugraha. 2004. "Problematika dalam Pengujian dan Pembatalan Perda Oleh Pemerintah Pusat. Jurnal Hukum Bisnis, Volume 23-No.1-Tahun 2004

Satjipto Rahardjo. 2009. Masalah Penegakan Hukum suatu Tinjauan Sosiologis. Bandung: Sinar Baru

Siwi Tri Puji. 2011. "Kemendagri temukan 329 Perda Bermasalah." www.detiknews.com/read/ [17-1-2011]

Sjachran Basah. 1985. Eksistensi dan Tolok Ukur Badan Peradilan Administrasi Negara. Bandung:Alumni

Soerjono Soekanto. 1983. Penegakan Hukum. Jakarta: Binacipta

Suko Wiyono. 1999. "Pengujian Keabsahan Peraturan Daerah dalam Rangka Penyelenggaraan Otonomi Daerah Berdasarkan Undang Undang Nomor 22 Tahun 1999 Tentang Pemerintahan Daerah". Ringkasan Disertasi. Malang: PPS Universitas Brawijaya Malang

Umbu Lily Pekuwali. 2010. "Eksistensi Perda dalam Mewujudkan Kesejahteraan Masyarakat”. Jurnal Yustisia FH UNS Surakarta, Terakreditasi Edisi Nomor 79, Januari-April 2010

UU No. 32 TAHUN 2004 tentang Pemerintahan Daerah

UU No.12 Tahun 2011 tentang Pembentukan Peraturan Daerah 